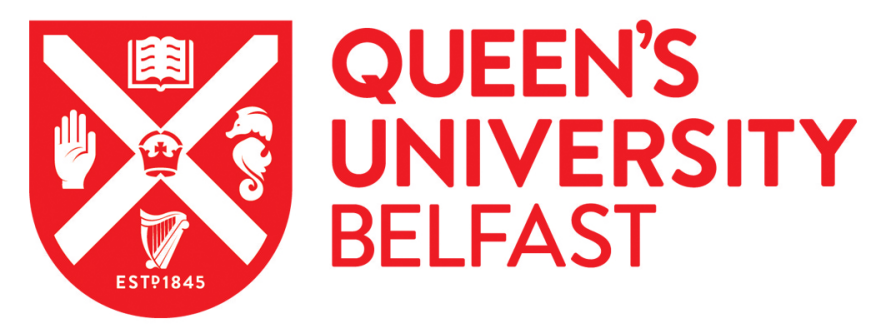

\title{
Creating institutional disruption: an alternative method to study institutions
}

Gidley, D. (2020). Creating institutional disruption: an alternative method to study institutions. Journal of Organizational Change Management, 34(4), 810-821. https://doi.org/10.1108/jocm-06-2019-0200

Published in:

Journal of Organizational Change Management

Document Version:

Peer reviewed version

Queen's University Belfast - Research Portal:

Link to publication record in Queen's University Belfast Research Portal

Publisher rights

Copyright $\odot$ 2020, Emerald Publishing Limited. This work is made available online in accordance with the publisher's policies. Please refer to any applicable terms of use of the publisher.

\section{General rights}

Copyright for the publications made accessible via the Queen's University Belfast Research Portal is retained by the author(s) and / or other copyright owners and it is a condition of accessing these publications that users recognise and abide by the legal requirements associated with these rights.

Take down policy

The Research Portal is Queen's institutional repository that provides access to Queen's research output. Every effort has been made to ensure that content in the Research Portal does not infringe any person's rights, or applicable UK laws. If you discover content in the Research Portal that you believe breaches copyright or violates any law, please contact openaccess@qub.ac.uk. 
Accepted copy for institutional repository

\section{Citation}

Gidley, D. (2020), "Creating institutional disruption: an alternative method to study institutions", Journal of Organizational Change Management, Vol. ahead-of-print No. ahead-of-print. https://doi.org/10.1108/JOCM-06-20190200

Accepted January 27, 2020

Published March 23, 2020

https://www.emerald.com/insight/content/doi/10.1108/JOCM-06-2019-0200/full/html

Deposit licences

Emerald allows authors to deposit their AAM under the Creative Commons Attribution Non-commercial International Licence 4.0 (CC BY-NC 4.0). To do this, the deposit must clearly state that the AAM is deposited under this licence and that any reuse is allowed in accordance with the terms outlined by the licence. To reuse the AAM for commercial purposes, permission should be sought by contacting permissions@emeraldinsight.com.

For the sake of clarity, commercial usage would be considered as, but not limited to: - Copying or downloading AAMs for further distribution for a fee;

- Any use of the AAM in conjunction with advertising;

- Any use of the AAM by for promotional purposes by for-profit organisations;

- Any use that would confer monetary reward, commercial gain or commercial exploitation. 


\title{
Creating Institutional Disruption: An Alternative Method to Study Institutions
}

\begin{abstract}
Purpose - This paper develops a new method to study institutions based on institutional work theory. Institutional disruption is intentionally utilized to explore the taken-for-granted foundations of social institutions. The paper outlines the method and considerations. Design/Methodology/Approach - Taking inspiration from ethnomethodological breaches, the paper outlines the steps in the new method called researcher initiated institutional disruption (RIID). The four steps are identifying the institution, identifying the institutional actors, selecting the disruption type, and disrupting the institution to gather data (action and reaction). RIID utilizes three types of institutional disruption: undermining assumptions and beliefs, resistance, and issue raising.
\end{abstract}

Findings - The new method complements traditional field methods, such as observation, by showing how a researcher can deliberately make taken-for-granted institutional features visible. The paper finds that RIID offers the opportunity to gather different data, but it is not appropriate for every study and carries potential consequences in the field.

Originality/value - This paper contributes to the literature by outlining an innovative use of theory as method. The approach has not previously been detailed and offers the potential to access previously inaccessible research questions, data, and theoretical insights.

\section{Key Words}

Institutional work, Institutional theory, Ethnomethodology, Method, Breaches, ethnography 


\section{Introduction}

Institutional work theory, "the purposive action of individuals and organizations aimed at creating, maintaining and disrupting institutions" (Lawrence and Suddaby, 2006, p. 215), can be redeployed as an alternative method to studying institutions. Building on literature that integrates institutional creation work with participatory action research (Dover and Lawrence, 2010) and temporary institutional breakdowns (Palmer et al., 2018), I focus on the institutional work category of disruption and the potential use in the field as a complement to existing method options (Lawrence and Suddaby, 2006, p. 238-246). Within observation centered methodologies, such as ethnography (Lok and de Rond, 2013) and organizational ethnography (Neyland, 2008; Rouleau et al., 2014), researchers will use a variety of methods to triangulate data (Stake, 1995). While "Methods in and of themselves are relatively atheoretical" (Carter and Little, 2007, p. 1324), the new method is specifically tied to the study of institutions but not limited to institutional theory in organizations (e.g. Martí and Fernández, 2013). This paper uses institutional work theory as a method, but it takes inspiration for the method from ethnomethodological breaches, "a procedure ... to modify the objective structure of the familiar, known-in-common environment by rendering the background expectancies inoperative" (Garfinkel, 1967, p. 54, emphasis in original), by proposing that a researcher intentionally disrupt an institutions as a means to study institutions, institutional actors, and institutional work.

The proposed method called researcher initiated institutional disruption (RIID) specifically focuses on studying social institutions - "regulative, normative, and cultural-cognitive elements that, together with associated activities and resources, provide stability and meaning to social life" (Scott, 2008, p. 48). Implicit in the proposed method is the understanding that institutions are somewhat, but not entirely, self-perpetuating and are formed and shaped by 
the ongoing action and interaction of institutional actors embedded within the institution (Oliver, 1992). Purposive institutional actions have been termed institutional work (Lawrence and Suddaby, 2006, p. 215). In contrast, "routinely and habitually reproduced" actions appear as institutional inertia and thus "present a problem for traditional empirical investigation" (Lawrence and Suddaby, 2006, p. 242). Using RIID as a method aims to uncover the hidden foundations of targeted institutions without seeking to permanently change institutions, as a dam would a river, but rather to momentarily reveal underlying features, as a stone creates temporary ripples.

The remaining paper is structured in the following way. First, I examine the problem the method aims to solve. Second, I review the literature on institutional work and ethnomethodology. Third, I describe the method in detail, providing hypotheticals from the literature and my own research. Finally, I discuss practical considerations and possible consequences.

\section{The problem}

Two aspects of institutions sometimes make underlying institutional norms, rules, and expectations hard to study. The first is the taken-for-granted nature of non-explicit rules and norms (Zucker, 1977; DiMaggio and Powell, 1983). In this, to use the conceptualization from Scott (2008), I refer to the normative and cultural-cognitive pillars and set aside the regulatory pillar for the moment (since those rules are more likely to be explicit in the form of laws and regulations). Taken-for-grantedness is specifically listed as the "basis of compliance" under the cultural-cognitive pillar (Scott, 2008, p. 51). The normative pillar based around "social obligation" also includes unwritten norms (Scott, 2008, p. 51). 
The social rules and norms are unwritten and unspoken in everyday life until they are broken. By definition, a taken-for-granted action is done without thinking about it, and therefore “conceals itself from observation" (Handel, 1982, p. 59). The issue becomes, how to uncover and understand the meaning of these institutional features, for the actors and for the institution. Organizational ethnography utilizes immersion and participant observation in an attempt to bring the outsider into the institution (Neyland, 2008). Observation allows for analysis and interpretation separate from informant accounts (Mikkelsen, 2013), but it can require lengthy, often impractical, stays in the field (Lok and De Rond, 2013). Managers in organizations rarely talk in explicitly institutional terms (Dover and Lawrence, 2010); however, the concept of "institutional judo" provides an exception (Hansen et al., 2015). RIID seeks to overcome the unreliability of embedded actors answering interview questions on things they never speak about and do without thinking. At most, an actor might admit to the decoupling of action and meaning (Meyer and Rowan, 1977; Pitsakis et al., 2012) or active resistance to change (Oliver, 1992).

\section{Institutions and Institutional Work}

Three aspects of institutions as studied through institutional theory are relevant in the development of this new method. First, most definitions of institutions consider them to be stable to some degree. Second, many definitions include a taken-for-granted element to institutional rules and norms. Third, actors embedded within an institution are beholden to the institution regardless of their self-awareness of their own institutional situation. All three present problems for researching institutions in the present tense and speculating on their future. 
The conception of institutions as stable and resistant to change traces its origins to early institutional theory writers (e.g. Selznick, 1948). The dominant image of institutional theory remains the "iron cage" trapping actors within a set of social rules and norms from which they cannot escape (DiMaggio and Powell, 1983). Actors are constrained by and within sets of institutional scripts that limit their ability to change existing institutional arrangements or to go outside the proverbial box. New institutional theorists used this image and neoinstitutional theory to help explain the stability and persistence of certain institutions. Actors occupying the same institutional field would eventually coalesce around a set of standards due to institutional pressures (DiMaggio and Powell, 1983). Two frequently studied examples include professional standards in medicine and accounting (Currie et al., 2012; Suddaby et $a l ., 2015)$. Explaining an institution or institutionalization was usually done as retrospective research by taking an institution and explaining via its history how it became institutionalized (e.g. DiMaggio, 1991).

Definitions of institutions within sociology and organization studies, working from a social construction of reality ontology (Berger and Luckmann, 1996), usually include a taken-forgranted element (e.g. Zucker, 1977; Scott, 2008), sometimes used as the benchmark of "full institutionalization" (Meyer et al., 2018, p. 406). Powell (1991, p. 191) suggests that institutional reproduction requires "taken-for-granted assumptions." Some taken-for-granted beliefs require institutional maintenance (Heaphy, 2013). The failure to do so leads to deinstitutionalization (Oliver, 1992).

Institutional work has become an increasingly popular theory for exploring the role and work of actors within institutional theory (Alvesson and Spicer, 2018). Citations for the original work defining institutional work (Lawrence and Suddaby, 2006) have passed 1,000 citations 
on Scopus. The theory does not challenge the theorization of institutions as stable; however, it states that institutions require not only actors acting out taken-for-granted scripts but also actors actively maintaining the institutions (Lawrence et al., 2013). Studying the actions that actors undertake to try and maintain or change institutions offers an ideal point for understanding the institutions themselves. Instead of retrospectively examining institutional change, institutional work allows for a present day focused examination of the everyday effects of actors on institutions and institutions on actors.

Institutional maintenance and institutional disruption are two categories of institutional work that can provide insight into current institutional rules and norms. Maintenance is aimed at keeping current institutional structures while disruption is aimed at destroying the same structures. Lawrence and Suddaby (2006, p. 230) identified various types of institutional maintenance aimed at supporting the normative or cognitive-cultural pillar of institutions: policing, valorizing and demonizing, and mythologizing. Other scholars have added new types such as repair work (Heaphy, 2013) and reenactment (Lok and de Rond, 2013). On the disruption side, undermining assumptions and beliefs was the only original type relating to those two pillars (Lawrence and Suddaby, 2006, p. 237), with resistance (Martí and Fernández, 2013) and issue raising (Karam and Jamali, 2013) being identified later. The connection between disruption and maintenance is made explicit in studies of institutional repair work, specifically in response to breaches (Heaphy, 2013).

\section{Breaches and ethnomethodology}

Breaches are an ideal way to determine what is taken-for-granted by disrupting the taken-forgranted interactions, making "seen but un-noticed" features of institutions visible (Garfinkel, 1967, p. 36). Ethnomethodology takes as its unit of analysis everyday interactions and thus is 
neither studying the individual micro nor societal macro level. In an empirical setting, this could mean the expected interaction between doctors and patients in different hospital types (Heaphy, 2013).

Ethnomethodology is not unknown in institutional studies. Prominent neo-institutionalists (Zucker, 1977; DiMaggio and Powell, 1991) have proposed using it to study institutions. In studies of institutional work, three studies looking at institutional maintenance haved used ethnomethodological methods. Heaphy (2013) focused on role breaches and the repair work required to maintain institutional roles in different hospital contexts. Palmer et al. (2015) use ethnomethodology's focus on everyday interaction in their observations of power relations in interorganizational settings. One of the researchers, playing the role of active participant, aimed to uncover the usual by treating it as unusual (Palmer et al., 2015). Palmer et al. (2018, p. 2182) "adopted the spirit" of breaches by providing students with textbooks contradicting university traditions. Their method "produced a temporary institutional breakdown" in order to "identify what work is significant to students (what matters to them)" (Palmer et al., 2018, p. 2178). The description of this short subsection of their methodology offers hints to similarities with RIID: intentional, targeted at a specific institution, focused on expectations, and lasting temporarily. Palmer et al. (2018) do not explicate the method; instead, the main activity is finding breaches within existing data (see also Fox, 2017).

RIID takes two inspirations from ethnomethodology: intentional breaches and reactions. The reason for this is that "Garfinkel does not study either institutions or individuals, but contexts of accountability, because this is where and how social institutions and individual members are reproduced, holistically" (Linstead, 2006, p. 400). With acknowledgement to previous work (Dover and Lawrence, 2010; Palmer et al., 2018; Fox, 2017), I propose to study 
institutions by examining not institutions or actors directly, but rather studying the reactions of actors to intentional disruptions of their institutional environment by the researcher.

\section{Bricolage for a new method}

In the following sections, I outline the four steps required of the RIID method. I provide two examples, both hypothetical and literature based. Finally, I address the moral implications and possible consequences of employing the method in research.

The new method shares some similarities with work by Fox (2017) on uncovering unseen aspects of nationalism. He proposes a new "research agenda" to do so by utilizing ethnomethodological breaches so that "otherwise taken-for-granted foundations can be momentarily revealed" (Fox, 2017, p. 27). The new method does the same thing for institutions, but with an important difference in how the breach is achieved. Fox (2017, p. 26) suggests that the researcher position herself at the spatial, temporal, or political "edge of the nation" so as to be better placed to observe frequently occurring national breaches and repairs. In this role, the researcher is still a passive observer which differentiates the approach from intentional breaches (Palmer et al., 2018). From a practical standpoint, participantobservation and ethnography require lengthy time investments from the researcher so as to increase the likelihood of serendipitous revelations (Neyland, 2008). Intentionally forcing the issue accelerates the process.

Engaging in institutional disruption as method requires intention on the part of the researcher to disturb institutional rules or norms in order to reveal them or their meaning for institutional actors. It would seem more accurate to call it intentional institutional disruption work; however, intention is already a part of the definition of institutional work (Lawrence and 
Suddaby, 2006, p. 215). Like the breaches described by Garfinkel (1967), RIID requires the researcher to "intentionally disrupt" a specific institution for a specific actor or set of actors (Handel, 1982, p. 73). Previous literature suggests that some actors will respond to disruption with repair work to maintain the institution (Heaphy, 2013; Micelotta and Washington, 2013). It is unlikely that all actors will react the same, so reactions including creation or disruption work are possible. The researcher should not force a reaction at all costs; therefore, some participants disregard for certain disruption is acceptable and should be collected as data. The researcher must differentiate ignoring as maintenance (Lok and de Rond, 2013) and ignoring as 'researcher peculiarity.' In such situations, an additional and alternative breach or set of actors can be considered in an effort to triangulate reactions (see step 2 and 3 below). Furthermore, if some participants do not recognize a breach as such, it speaks to institutional control, the social placement of actors within the institution, and the degree of institutionalization for the disrupted aspect or in general.

RIID can be used for known or unknown aspects. As an exploratory technique, the researcher probes the institutional fabric to divulge tacit boundaries and expectations. Once known, the researcher can extend the method to target specific actions to reveal latent meaning for institutional actors. In practice, the two may appear in the same interaction sequence as the researcher reacts to participants' reaction. In this way, "The actions of the researchers and participants in a research project constitute the methods of that project" (Carter and Little, 2007, p. 1325). There are four steps to the method are outlined in Table \#1 below.

** Insert Table 1 About Here ${ }^{* *}$ 
As a method for studying institutions, the researcher must identify the institution to be studied. Recent critiques of institutional theory have called out researchers for vagueness and omission on this point (Alvesson and Spicer, 2018). Naming the institution does not necessitate knowing the taken-for-granted rules and norms that make up the institution. Explicit rules may be conveyed at the outset, but implicit or institutional rules are discovered in the institutional setting. The method will uncover certain institutional features during fieldwork and the researcher will observe others, but full interpretation is done during data analysis. For example, Siebert et al. (2018) clearly state they are studying the institution of Scottish advocates within two professional spaces. At the field site, they record a complex system seniority and status that restricts spatial access. Later, in data analysis, they define the spaces as enchanted (Siebert et al., 2018). Defining the institution allows for the possibility of institutional work and institutional meaning. Fox (2017, p. 33) writes, "It's the airport as an institution marking national boundaries that makes both the understanding of the breach and the repair work that follows it explicitly national." The researcher must be aware of the certainty of institutional multiplicity in any social setting - every actor will be embedded within multiple institutions simultaneously (Zilber, 2011). It is possible to target, but not isolate as in a laboratory setting, a specific institution. Likewise, some actors can temporarily enter more formal institutions before leaving again, as in the case of emergency response callers (Hak, 1995). The researcher is responsible for defining the institution and justifying the analytical boundaries. In my own research, I identified a single industry incubator as an institution based on criteria in existing literature. The incubator comprised the majority of the national field (Zilber, 2011), including a significant support organization (Palmer et al., 2015), aimed to isomorphically professionalize the industry (Currie et al., 2012; DiMaggio and Powell, 1983), and continued beyond a particular set of actors (Zucker, 1977). 


\section{Identify the institutional actors and researcher role}

The second step in the method is to identify the institutional actor or actors for the social experiment. Various considerations and issues arise. First, the actor must belong to the institution identified in step one. Identifying such an actor might be easy based on a specific boundary where the institution is known to hold sway such as time (e.g. Lok and de Rond, 2013) or space (e.g. Siebert et al., 2018). Broader reaching institutions can make it more difficult to narrow down possible actors due to the multitude of possible subjects (e.g. Karam and Jamali, 2013). Next, the actor might be a central figure within the institution (Hardy and Maguire, 2010) or marginalized (Martí and Mair, 2009). For example, the pervasiveness of the British class system provides millions of possible actors, but ritualized interface areas offer a rich source of data (Dacin et al., 2010). The embeddedness of actors within the institution will reveal different institutional features. The researcher must choose the actor based on the research question and justify the rationale for choosing a certain type of actor for the experiment.

Included in the second step is the role the researcher will play. There are three possible scenarios for the researcher-informat relationship. First, the researcher can be a noninstitutional actor, such as an academic researcher studying a hi-tech conference (Zilber, 2011). This is the typical role found in ethnography (Bjerregaard, 2011). Second, the researcher can be an institutional actor within the institution being studied, such as a student studying students (Dacin et al., 2010). In these cases, a third option is presented as the researcher must decide whether to assume the role of herself as institutional actor or play a different role as a non-institutional actor. The choice may not always be clear, especially in empirical settings such as academia (e.g. Palmer et al., 2018). The final consideration is based on the degree of researcher embeddedness in the field. In longer term studies, such as 
ethnographies, the researcher can become integrated into the institutional landscape even if she never fully becomes an institutional actor. Familiarity might amplify or mitigate disruption depending on the situation. Written accounts should describe the chosen role and emplacement.

\section{Select institutional disruption type to use}

The third step in the method is to select the appropriate type or types of institutional disruption work to use as the breach in the institution. The contextual nature of empirical research means that the researcher will not know the specific and explicit forms of institutional disruption to enact before entering the field. There are three types that can be employed alone or in combination, and there is overlap between them (see table \#2 below). Among the original types identified by Lawrence and Suddaby (2006, p. 235), undermining assumptions and beliefs is the one type that can be used to research the normative and cultural-cognitive foundations of institutions. Lawrence and Suddaby (2006, p. 235) define this type as "Decreasing the perceived risks of innovation and differentiation by undermining core assumptions and beliefs." This type is most closely related to the social breaches of Garfinkel as it seeks to understand institutional foundations by questioning things institutional actors take for granted. As utilized in this method, the type is reactive since it relies on the researcher reacting to institutional norms enacted by the informant. The simplest way to do this is to ask the informant to continuously elaborate on each statement.

The two other types come from newer institutional work literature and place the researcher in a more active role of disrupting the institution. The second type of institutional disruption work a researcher can employ is resistance. Within the institutional work perspective, Martí and Fernández (2013, p. 1206) describe resistance as "efforts which, whether mundane or 
extraordinary, can be seen as refusals to concede the superiority of the oppressor."

Deliberately refusing to comply with institutional norms, rules, and pressures, pushes against the proverbial "iron cage" constraining institutional actors within prescribed institutional structures and reveals the structures themselves (DiMaggio and Powell, 1983). Resistance can prompt institutional actors to engage in policing (Lawrence and Suddaby, 2006, p. 231), repair work (Micelotta and Washington, 2013), defensive work (Maguire and Hardy, 2009), or decoupling (Pitsakis et al., 2012) to counter disruptive actions. All three institutional work responses can provide insights into the foundations and strengths of the institution.

Researcher resistance in the field to existing power structures or institutional norms has been noted in reflective accounts (Mikkelsen, 2013).

The last type of institutional disruption work is issue raising. Karam and Jamali (2013, p. 38) incorporate issue raising from Social Movement literature into the existing institutional work literature and define it as "Purposely raising the visibility of a " $\mathrm{xxx}$ " issue by placing it within the context of field actors and therefore increasing the relevance of the issue for status quo actors." Issue raising involves the researcher as a reflexive institutional actor or unembedded outsider bringing up an issue affecting certain institutional actors either with the actors strongly or weakly constrained by the institutional issue. Oftentimes, this will be seen as a challenge to the status quo and prompt a response from embedded institutional actors that had not previously considered the issue. In the case of gender issues in the Middle East, Karam and Jamali (2013) describe various CSR initiatives that challenge the institutional order in the region. Discourse aimed at raising awareness functions as institutional work breaching the patriarchal status quo. The difference between undermining assumptions and beliefs and issue raising lies in the initiation of the disruption. Issue raising is active in that the researcher 
seeks out contradictions or moral problems with the institution and provokes a response from institutional actors. Issue raising can take the form of hypothetical stories.

** Insert Table 2 About Here ${ }^{* *}$

\section{Disrupt the institution and collect data}

The fourth step in the method is disrupting the institution and collecting data. Innovative data collection is possible with this method; however, I will focus on the primary components. As in ethnomethodology, what informats say in reaction to the institutional disruption forms the first data set (Garfinkel, 1967). As in institutional work, what informats do in reaction forms the second set of data (Lawrence and Suddaby, 2009, p. 1). After the initial disruption is over, a researcher should consider interviewing the informant, formally or informally, to gain access to the "sensemaking" done by the institutional actor in relation to the disruption (Weick, 1995). If any other institutional actors were present or involved, the same should be done with them as well in an effort to triangulate the data and add to the interpretation (Stake, 1995). In written accounts of the disruption action and reaction, the researcher must record her own role and actions in the same detail as others. In field notes, this will help the researcher in the data analysis stage, and in publication, it will help the reader in judging the work. The data, that is interaction, is formed by both parties (Watzlawick and Beavin, 1967).

\section{The method in practice}

The method outlined above requires boldness, flexibility, and inventiveness from a researcher. The required skills are different than participant observation, and it would be useful to provide a practical example of the method in action. Below, I provide two possible examples, one from existing literature and one from my own research. I discuss how the 
method might have been used as neither example used RIID as outlined in this paper. Both interorganizational spaces contained power dynamics that constrained some actors but not the researcher, therefore opening up opportunities for a researcher to do what participants cannot (Mikkelsen, 2013).

The first literature example comes from a case study of buyer-seller power relations and institutional maintenance in an industrial workshop setting (Palmer et al., 2015). The workshop is temporally and spatially bound, but the retailer has institutionalized the workshop by repeating it with different employees and suppliers in multiple locations. Since the research question seeks to understand power relations, it makes sense to target the powerful (i.e. the retailer) by utilizing RIID. Initial observations provide the rationale to deploy the method as the authors include a picture that shows a white board with sticky note questions from suppliers. The board is mostly empty, and an informant says that experienced suppliers know not to ask questions (Palmer et al., 2015). This information prompts the researcher using RIID to do the opposite, that is, raise an issue by posting a question and observe the demonstration of power within the institution. The reaction to the posting itself and to the question both offer up data for analysis. In this case, the researcher has the opportunity to post multiple questions and observe the exercise of power across multiple points. To summarize, the institution is the industrial workshop, the institutional actors are the retailer and suppliers, the disruption type is issue raising, data collection will come from observation and interviews, and the analysis reveals how power is exercised in the institution.

Second, I present one hypothetical example from my own ethnographic research into an interorganizational video game incubator. Assuming the role of 'objective' outsider, I would focus on all the companies participating in a six week long scheme requiring a new game a 
week. By introducing a ranking or reward system, I would undermine assumptions and beliefs by introducing artificial competition to explore the institutional culture of noncompetition. Since each week produced a new game, there might be the opportunity to utilize resistance to any institutional maintenance work. I would initiate something that is not there to see what is there.

\section{Moral implications and possible consequences}

There are limitations, moral implications, and possible consequences to using RIID that should be considered before proceeding. The method is not participatory action research (Dover and Lawrence, 2010); therefore, it does not seek to permanently change institutions nor test a hypothesis (Palmer et al., 2018). The method can be used with all types of institutions and institutional actors although some are preferable to others. Stronger, older institutions and more embedded actors are likely to produce more visible reactions than weaker or proto-institutions (Lawrence et al., 2002). The same moral issues raised about ethnomethodology's breaching experiments can be applied to intentional institutional disruption by a researcher, including the lack of full and explicit informed consent, risks to informants and the researcher in the present and future (Handel, 1982, p. 74-75). When confronted with disruption, highly embedded and emotionally invested actors may react unpredictably and dangerously (e.g. Martí and Fernández, 2013). Loss of access to research sites or participants is a very real possibility and may not be worth the data collected (Handel, 1982, p. 74-75). As with other interpretive research, it is important for a researcher to be reflexive and consider her role in relation to the institution and institutional actors (Mikkelsen, 2013; Dacin et al., 2010). 
Three main ethical considerations deserve further attention. First, the method does not preclude, and usually expects, a degree of informed consent. In this way, it differs from classic ethnomethodological breaches. The researcher can use RIID as an additional method in an already accessed institutional setting where the organization or participants are informed of the research. Participant-observation and interaction inherently carries the risk of unintended and negative consequences (Neyland, 2008; Bell, 2010). The goal is to minimize, but "we do leave tracks" (Fine and Shulman, 2009, p. 187). Using the method might leave institutional remnants as ephemeral as an uncomfortable interview question or as enduring as observing reportable illegal activity. The intention is not to create lasting impact on an institution, nor is it likely considering the "plasticity" of institutions (Lok and de Rond, 2013). Second, the method is only as valuable as its design and application in the field. The goal is to aid in contributing to scientific knowledge. If the preceiveable costs, in the multitude of definable ways, outweigh the expected benefits, then the researcher should use other methods. Third, like other alternative methods such a covert observation, ethical review boards may reject RIID as "as dangerous, unscientific or harmful within the context of this regulatory discourse" (Bell, 2010, p. 132). In response, there are three ethical defenses. As noted above, RIID may be more or less risky depending on application in the field. RIID is based within an interpretive epistemology and established social scientific tradition, notably sociology (Rouleau et al., 2014; Lawrence and Suddaby, 2006). Finally, the method relies on the ethnographic ethical spirit that "do no harm is a prime injunction" (Fine and Shulman, 2009 , p. 187). Disruption does not equate to harm in the same way that conflict does not equate to violence (Mikkelsen, 2013).

What Mehan and Wood (1975, p. 513) said about ethnomethodology applies to the new method as well: "It is an activity that forces the practitioner to take risks." Several techniques 
can lower the possible risk. Humor is commonly used to disarm and convey information without provoking direction confrontation over an issue (Stokoe, 2008). Pleading ignorance places the researcher in the position of wanting to learn and gives the subject responsibility for teaching. Curiosity, usually in the form of saying 'I wonder' or repeatedly asking for further explanation (Garfinkel, 1967), places the researcher in a learning position as opposed to a confrontational position that might end the research.

\section{Conclusion}

Institutions remain a very popular research topic in studies of organization and management (Alvesson et al., 2019). As formerly marginal methodologies in organization studies, such as ethnography (Bjerregaard, 2011), have become more prevalent, new methods like RIID build on previous innovations (Lawrence and Suddaby, 2006; Dover and Lawrence, 2010; Palmer et al., 2018). Lack of legitimacy in the research community hinders the adoption of any new method, although success somewhere can lead to acceptance elsewhere (Hansen et al., 2015). Disruption carries a negative connotation that creation does not, perhaps adding an additional barrier to ethical approval, and later, academic community acceptance. Deeper discussion and incorporation with organizational ethnography offers a potential path for further development. ${ }^{1}$ Like participant-observation, the necessary interactive nature of the method puts additional pressure on the researcher in the field. Some may consider it noteworthy that in my own research, I have not fully utilized RIID, as of yet, despite opportunities in the field. Ultimately, the research question, and to a lesser extent the empirical setting and actors, determines the usefulness of selecting RIID as a method to study institutions. The method can uncover data otherwise unobtainable thereby making it an optional tool for researchers in the field.

\footnotetext{
${ }^{1}$ Thank you to the anonymous reviewer for suggesting this.
} 


\section{References}

Alvesson, M., Hallett, T., and Spicer, A. (2019), "Uninhibited institutionalisms", Journal of Management Inquiry, Vol. 28 No. 2, pp. 119-127.

Alvesson, M., and Spicer, A. (2018), "Neo-Institutional theory and organization studies: A mid-life crisis?", Organization Studies, Vol. 40 No. 2, pp. 199-218.

Bell, E. (2010), "Managerialism and Management Research: Would Melville Dalton Get a Job Today?", In Cassell, C. and Lee, B., (Eds), Challenges and Controversies in Management Research. Routledge, Abingdon, UK, pp. 122-137.

Berger, P.L. and Luckmann, T. (1966), The Social Construction of Reality: A Treatise in the Sociology of Knowledge. Doubleday and Company, New York.

Bjerregaard, T. (2011), "Studying institutional work in organizations: Uses and implications of ethnographic methodologies", Journal of Organizational Change Management, Vol. 24 No. 1, pp. 51-64.

Carter S. M, and Little M. (2007), “Justifying knowledge, justifying method, taking action: epistemologies, methodologies, and methods in qualitative research", Qualitative Health Research, Vol. 17 No. 10, pp. 1316-1328.

Currie, G., Lockett, A., Finn, R., Martin, G., and Waring, J. (2012), "Institutional work to maintain professional power: Recreating the model of medical professionalism", Organization Studies, Vol. 33 No. 7, pp. 937-962.

Dacin, M. T., Munir, K., and Tracey, P. (2010), "Formal dining at cambridge colleges: Linking ritual performance and institutional maintenance", Academy of Management Journal, Vol. 53 No. 6, pp. 1393-1418.

DiMaggio, P. (1991), “Constructing an organizational field as a professional project: US art museums, 1920-1940”, In Powell, W.W., DiMaggio, P.J., (Eds), The New Institutionalism in Organizational Analysis; The University of Chicago Press, Chicago, pp. 267-292.

DiMaggio, P., and Powell, W. (1983), "The iron cage revisited: Institutional isomorphism and collective rationality in organizational fields", American Sociological Review, Vol. 48 No. 2, pp. 147-160.

Dover, G., and Lawrence, T. B. (2010), “A gap year for institutional theory: Integrating the study of institutional work and participatory action research, Journal of Management Inquiry, Vol. 19 No. 4, pp. 305-316. 
Fine, G. and Shulman, D. (2009), "Lies from the field: ethical issues in organizational ethnography”, In S. Ybema D. Yanow \& H. Wels (Eds.), Organizational ethnography: Studying the complexities of everyday life; SAGE Publications, London, pp. 177-195.

Fox, J. E. (2017), "The edges of the nation: a research agenda for uncovering the taken-forgranted foundations of everyday nationhood", Nations and Nationalism, Vol. 23 No. 1, pp. 26-47.

Garfinkel, H. (1967), Studies in Ethnomethodology. Prentice-Hall, Englewood Cliffs, NJ.

Hak, T. (1995), "Ethnomethodology and the institutional context", Human Studies, Vol. 18 No. 2/3, pp. 109-137.

Handel, W. (1982), Ethnomethodology: How People Make Sense, Prentice-Hall, Englewood Cliffs, NJ.

Hansen, H., Randolph, A., Chen, S., Robinson, R., Marin, A. and Lee, J. (2015), "Institutional judo: how entrepreneurs use institutional forces to create change", Journal of Organizational Change Management, Vol. 28 No. 6, pp. 1076-1093.

Hardy, C., and Maguire, S. (2010), "Discourse, field-configuring events, and change in organizations and institutional fields: Narratives of DDT and the Stockholm convention. Academy of Management Journal, Vol. 53 No. 6, pp. 1365-1392.

Heaphy, E. D. (2013), "Repairing breaches with rules: Maintaining institutions in the face of everyday disruptions”, Organization Science, Vol. 24 No. 5, pp. 1291-1315.

Karam, C. M., and Jamali, D. (2013), "Gendering CSR in the Arab Middle East: An institutional perspective”, Business Ethics Quarterly, Vol. 23 No. 1, pp. 31-68.

Lawrence, T. B., Hardy, C., and Phillips, N. (2002), "Institutional effects of interorganizational collaboration: The emergence of proto-institutions", Academy of Management Journal, Vol 45 No. 1, pp. 281-290.

Lawrence, T. B., Leca, B., and Zilber, T. B. (2013), "Institutional work: current research, new directions and overlooked issues”, Organization Studies, Vol. 34 No. 8, pp. 1023-1033.

Lawrence, T. B. and Suddaby, R. (2006), "Institutions and institutional work". In Clegg, S., Hardy, C., Lawrence, T. B., and Nord, W. (Eds), Sage Handbook of Organization Studies, 2nd Edition, Sage, London, pp. 215-254.

Linstead, S. (2006), "Ethnomethodology and sociology: an introduction", Sociological Review, Vol. 54 No. 3, pp. 399-404. 
Lok, J., and De Rond, M. (2013), "On the plasticity of institutions: Containing and restoring practice breakdowns at the Cambridge University Boat Club”, Academy of Management Journal, Vol. 56 No. 1, pp. 185-207.

Maguire, S., and Hardy, C. (2009), "Discourse and deinstitutionalization: The decline of DDT”, Academy of Management Journal, Vol, 52 No. 1, pp. 148-178.

Martí, I., and Fernández, P. (2013), "The institutional work of oppression and resistance: Learning from the Holocaust”, Organization Studies, Vol. 34 No. 8, pp. 1195-1223.

Martí, I., and Mair, J. (2009), "Bringing change into the lives of the poor: Entrepreneurship outside traditional boundaries", In T. Lawrence, R. Suddaby, and B. Leca (Eds.), Institutional Work: Actors and Agency in Institutional Studies of Organizations. Cambridge University Press, Cambridge, pp. 92-119.

Mehan, H., and Wood, H. (1975), "The morality of ethnomethodology”, Theory and Society, Vol. 2 No. 4, pp. 509-530.

Meyer, R. E., Jancsary, D., Höllerer, M. A., and Boxenbaum, E. (2018), “The role of verbal and visual text in the process of institutionalization", Academy of Management Review, Vol. 43 No. 3, pp. 392-418.

Meyer, J., and Rowan, B. (1977), "Institutionalized organizations: Formal structure as myth and ceremony", American Journal of Sociology, Vol. 83 No. 2, pp. 340-363.

Micelotta, E. R., and Washington, M. (2013), “Institutions and maintenance: the repair work of Italian professions”, Organization Studies, Vol. 34 No. 8, pp. 1137-1170.

Mikkelsen, E. N. (2013), “A researcher's tale: How doing conflict research shapes research about conflict", Qualitative Research in Organizations and Management, Vol. 8 No. 1, pp. $33-49$.

Neyland, D. (2008), Organizational Ethnography, Sage, London.

Oliver, C. (1992), “The antecedents of deinstitutionalization”, Organization Studies, Vol. 13 No. 4 , pp. $563-588$.

Palmer, M., deKervenoael, R., and Jacob, D. (2018), “Temporary institutional breakdowns: the work of university traditions in the consumption of innovative textbooks", Studies in Higher Education, Vol. 43 No. 12, pp. 2176-2193.

Palmer, M., Simmons, G., Robinson, P. K., and Fearne, A. (2015), "Institutional maintenance work and power preservation in business exchanges: Insights from industrial supplier workshops", Industrial Marketing Management, Vol. 48, 214-225. 
Pitsakis, K., Biniari, M. and Kuin, T. (2012), "Resisting change: organizational decoupling through an identity construction perspective", Journal of Organizational Change Management, Vol. 25 No. 6, pp. 835-852.

Rouleau, L., de Rond, M. and Musca, G. (2014), "From the ethnographic turn to new forms of organizational ethnography", Journal of Organizational Ethnography, Vol. 3 No. 1, pp. 29.

Scott, W.R. (2008), Institutions and Organizations: Ideas and Interests, 3rd ed., Sage Publications, Los Angeles, CA.

Selznick, P. (1948), "Foundations of the theory of organization", American Sociological Review, Vol. 13 No. 1, pp. 25-35.

Siebert, S., Wilson, F., and Hamilton, J. R. A. (2017), “'Devils May Sit Here:' the Role of Enchantment in Institutional Maintenance", Academy of Management Journal, Vol. 60 No. 4, pp. 1607-1632.

Stokoe, E. (2008), "Dispreferred actions and other interactional breaches as devices for occasioning audience laughter in television 'sitcoms", Social Semiotics, Vol. 18 No. 3, pp. 289-307.

Stake, R. (1995), The Art of Case Study Research, Sage, Thousand Oaks, CA.

Suddaby, R., Saxton, G. D., and Gunz, S. (2015), “Twittering change: The institutional work of domain change in accounting expertise", Accounting, Organizations and Society, Vol. 45, pp. 52-68.

Watzlawick, P., and Beavin, J. (1967), "Some formal aspects of communication", American Behavioral Scientist, Vol. 10 No. 8, pp. 4-8.

Weick, K. E. (1995), Sensemaking in organizations, Sage, Thousand Oaks, CA.

Zilber, T. (2011), "Institutional multiplicity in practice: A tale of two high-tech conferences in Israel", Organization Science, Vol. 22 No. 6, pp. 1539-1559.

Zucker, L. (1977), "The role of institutionalization in cultural persistence", American Sociological Review, Vol. 42 No. 5, pp. 726-743. 